\title{
HUBUNGAN KEBIASAAN MEROKOK DAN pH SALIVA DENGAN KESEHATAN GIGI DAN MULUT PADA MASYARAKAT DESA PATUMBAK I KECAMATAN PATUMBAK KABUPATEN DELI SERDANG
}

\author{
Intan, Asmawati, Sondang \\ Dosen Jurusan Keperawatan Gigi Poltekkes Kemenkes Medan
}

\begin{abstract}
Abstrak
Kebiasaan merokok merupakan salah satu faktor terjadinya karies gigi karena adanya kandungan tembakau seperti tar ,nikotin, dapat diendapkan pada permukaan gigi dan akar gigi sehingga permukaan menjadi kasar dan mempermudah perlekatan plak. Saliva bekerja sebagai buffer , mengatur $\mathrm{pH}$ rongga mulut ketika keadaan rongga mulut asam. Kemampuan saliva dalam menetralisasi asam pada perokok lebih rendah, sehingga berdampak pada kerentanan terhadap karies gigi. Penelitian ini adalah penelitian survey analitik dengan desain cross sectional. Yang bertujuan untuk mengetahui hubungan kebiasan merokok dan $\mathrm{pH}$ saliva dengan kesehatan gigi dan mulut. Analisa data dilakukan dengan One Way Anova dengan hasil: Ada hubungan yang signifikan antara merokok dengan status kebersihan gigi dan mulut (Debris $p=0,011$; Kalkulus $\mathrm{p}=0,001$; OHI-S $\mathrm{p}=0,006)$, Karies $(\mathrm{p}=0,000)$ dan Gingivitis $(\mathrm{p}=0,021)$. Tidak ada hubungan yang signifikan antara lama merokok dengan status kebersihan gigi dan mulut (Debris $\mathrm{p}=0,268$; Kalkulus $\mathrm{p}=0,826$ ; OHI-S p=0,922), sedangkan untuk Karies dan Gingivitis diperoleh ada hubungan yang signifikan dengan Lama Merokok (Karies $p=0,000)$ dan Gingivitis $(p=0,013$ ). Ada hubungan yang signifikan antara $\mathrm{pH}$ Saliva dengan status kebersihan gigi dan mulut (Debris $\mathrm{p}=0,000$; Kalkulus $\mathrm{p}=0,004$; OHI-S $\mathrm{p}=0,001$ ), Karies $(\mathrm{p}=0,039)$ dan Gingivitis $(\mathrm{p}=0,007)$. Dapat disimpulkan bahwa ada hubungan merokok dan keadaan $\mathrm{pH}$ saliva dengan status kesehatan gigi dan mulut di Desa Patumbak I Kecamatan Patumbak Kabupaten Deli Serdang. Diharapkan kepada masyarakat untuk menghentikan kebiasaan merokok dan pemerintah giat melaksanakan kampanye anti rokok.
\end{abstract}

Kata kunci : Rokok, pH Saliva, Kesehatan Gigi dan Mulut

\section{PENDAHULUAN}

Rokok adalah silinder dari kertas berukuran panjang antara 70 hingga $120 \mathrm{~mm}$ dengan diameter sekitar $10 \mathrm{~mm}$ yag berisi daun-daun tembakau yang telah dicacah. Rokok dibakar pada salah satu ujungnya dan dibiarkan membara agar asapnya dapat dihirup lewat mulut pada ujung (Jaya, 2012).

Data WHO (2013) menyatakan di negara berkembang jumlah perokoknya 800 juta orang, hampir tiga kali lipat Negara maju. Setiap harinya sekitar 80100 ribu remaja di dunia yang menjadi pecandu dan ketagihan rokok. Bila pola ini terus menetap maka sekitar 250 juta anak-anak yang hidup sekarang ini akan meninggal akibat penyakit yang ditimbulkan akibat efek merokok. Dampak saat ini Indonesia menduduki peringkat ke 5 dalam konsumsi rokok dunia.

Berdasarkan Riset Kesehatan Dasar (2013) prevalensi merokok di Indonesia sebesar 29,3 \%. Merokok tidak hanya menimbulkan efek secara sistemik, tetapi juga dapat menyebabkan timbulnya kondisi patologis di rongga mulut. Gigi dan jaringan lunak rongga mulut, merupakan bagian yang dapat mengalami kerusakan akibat rokok. Penyakit periodontal, karies, kehilangan gigi, resesi gingiva, lesi prekanker, kanker mulut, serta kegagalan implan adalah kasus-kasus yang dapat timbul akibat kebiasaan merokok. (Mubeen K, 2013).

Kebiasaan merokok merupakan salah satu faktor terjadinya karies gigi karena adanya kandungan tembakau seperti tar ,nikotin, dapat diendapkan pada permukaan gigi dan akar gigi sehingga permukaan menjadi kasar dan mempermudah perlekatan plak (Jaya, 2012)

Menurut Riskesdas 2013 peningkatan prevalensi terjadinya karies aktif pada penduduk Indonesia dibandingkan tahun 2007 lalu, yaitu dari 43,4 \% menjadi 53,2 \%.

Kecamatan Patumbak sebagai bagian dari linggar luar kabupaten Deli Serdang menunjukkan pasien yang datang berobat ke puskesmas Patumbak tahun 2016 diperoleh pasien berobat karena penyakit dan keluhan penyakit gigi 24 pasien setiap bulannya dari jumlah pasien berobat dengan keluhan penyakit gigi dan mulut yang ada di puskesmas sebanyak 17 orang yang menderita karies 
dan gingivitis atau sebesar 70,8\%, dan juga berdasarkan survey awal yang telah dilakukan pada bulan Oktober 2016 pada 10 orang perokok di Desa Patumbak I Kecamatan Patumbak Kabupaten Deli Serdang ditemukan angka kejadian karies tinggi yaitu enam dari sepuluh orang menderita karies atau sebesar $60 \%$.

\section{Rumusan Masalah}

Apakah ada hubungan kebiasan merokok dan $\mathrm{pH}$ Saliva dengan kesehatan gigi dan mulut pada Masyarakat Desa Patumbak I Kecamatan Patumbak Kabupaten Deli Serdang Tahun 2017.

\section{Tujuan Penelitian \\ Umum}

Untuk mengetahui hubungan kebiasan merokok dan $\mathrm{pH}$ saliva dengan kesehatan gigi dan mulut di Desa Patumbak I Kecamatan Patumbak Kabupaten Deli Serdang

\section{Tujuan Khusus}

a. Untuk mengetahui gambaran kebiasaan merokokdan $\mathrm{pH}$ saliva

b. Untuk mengetahui keadaan kesehatan gigi dan mulut (OHIS, Karies, gingivitis)

\section{Manfaat Penelitian}

a. Bagi masyarakat untuk mengetahui akibat dari merokok terhadap kesehatan gigi dan mulut

b. Bagi Instansi Kesehatan, hasil penelitian dapat memberikan masukan kepada pemerintah

c. Bagi Peneliti dapat menambah wawasan peneliti dan sumbangsih bagi khasana ilmu

\section{Urgensi Penelitian}

Hasil dari penelitian ini menjadi informasi bagi masyarakat tentang bahaya merokok bukan hanya berdampak pada kesehatan juga penyakit gigi dan mulut untuk selanjutnya dapat dibuat suatu kegiatan penyuluhan tentang bahaya merokok terhadap kesehatan gigi dan mulut

\section{METODE PENELITIAN}

\section{Jenis dan Desain Penelitian}

Penelitian ini adalah penelitian survey analitik dengan desain cross sectional. Yang bertujuan untuk mengetahui hubungan kebiasan merokok dan $\mathrm{pH}$ saliva dengan kesehatan gigi dan mulut di Desa Patumbak I Kecamatan Patumbak Kabupaten Deli Serdang.

\section{Lokasi dan Waktu Penelitian}

Penelitian ini dilakukan di Desa Patumbak I Kecamatan Patumbak Kabupaten Deli Serdang yang berada di wilayah kerja puskesmas Patumbak

\section{Populasi dan Sampel Penelitian}

Populasi adalah masyarakat di Desa Patumbak I yang terdiri atas VI Dusun di Kecamatan Patumbak Kabupaten Deli Serdang.Sampel dalam penelitian ini berjumlah 128 orang.

\section{Teknik Sampling}

Pengambilan sampel dilakukan dengan Purposive sampling sampel yang dipilih telah memenuhi kriteria inklusi dan eksklusi.

1. Kriteria Inklusi :

a. Masyarakat Desa Patumbak I Kabupaten Deli Serdang.

b. Pria Dewasa berusia 17 tahun ke atas.

2. Kriteria Ekslusi :

a. Pria Dewasa yang menderita penyakit sistemik.

b. Tidak sedang menggunakan obat-obatan.

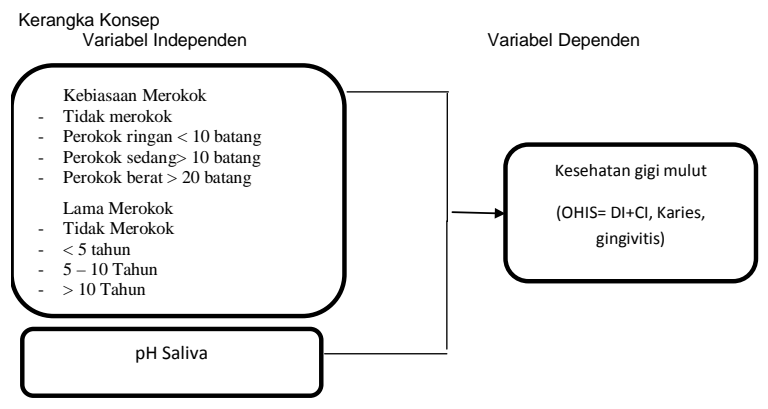

Variabel dan Definisi Operasional

\begin{tabular}{|c|c|c|c|c|}
\hline No & Variabel & Definisi Operasional Alat Ukur & $\begin{array}{ll}\text { Hasil } & \text { Peng- } \\
\text { ukuran }\end{array}$ & Skala \\
\hline 1 & $\begin{array}{l}\text { Kebiasaan } \\
\text { merokok }\end{array}$ & $\begin{array}{l}\text { Kebiasaan merokok } \\
\text { merupakan peng- } \\
\text { ulangan merokok } \\
\text { secara } \quad \text { terus } \\
\text { merm } \\
\text { menerus atau dalam } \\
\text { sebagian } \quad \text { besar } \\
\text { waktu }\end{array}$ & $\begin{array}{l}\text { - } \quad \text { Tidak } \\
\text { merokok } \\
\text { - Ringan } \\
\text { - Sedang } \\
\text { - Berat }\end{array}$ & Ordinal \\
\hline 2 & $\begin{array}{l}\text { Lama } \\
\text { merokok }\end{array}$ & $\begin{array}{l}\text { Lamanya seseorang } \\
\text { telah menjadi Form } \\
\text { perokok tetap }\end{array}$ & $\begin{array}{l}-\quad \text { Tidak } \\
\text { merokok } \\
-<5 \text { tahun } \\
-5-10 \text { tahun } \\
->10 \text { tahun }\end{array}$ & Ordinal \\
\hline 3 & $\mathrm{pH}$ saliva & $\begin{array}{l}\text { Keadaan keasaman } \\
\text { saliva }\end{array}$ & $\begin{array}{l}\text {-Asam } \\
\text {-Netral } \\
\text {-Basa } \\
\end{array}$ & Ordinal \\
\hline 4 & OHIS & $\begin{array}{l}\text { Keadaaan } \\
\text { kebersihan gigi dan }) \mathrm{HI} \\
\text { mulut }\end{array}$ & $\begin{array}{l}\text { DI } \\
\text { CI } \\
\text { OHIS } \\
\end{array}$ & Interval \\
\hline 5 & Karies & $\begin{array}{l}\text { Karies gigi adalah } \\
\text { pe-nyakit jaringan } \\
\text { gigi yang ditandai } \\
\text { dengan keru-sakan } \\
\text { jaringan, dimulai } \\
\text { dari permukaan gigi } \\
\text { (pit, fissure dan }{ }^{\text {}} \text { )MFT } \\
\text { daerah inter- } \\
\text { proksimal) meluas } \\
\text { kearah pulpa yang } \\
\text { diukur } \\
\text { menggunakan } \\
\text { indeks DMFT }\end{array}$ & Indeks karies & Interval \\
\hline 6 & Gingivitis & $\begin{array}{ll}\text { Kerusakan } & \text { Ideks } \\
\text { pada gingiva } & \text { ingivitis }\end{array}$ & Angka indeks & Interval \\
\hline
\end{tabular}

Pengolahan Data dan Analisa Data

Pengolahan data dilakukan dengan univariat untuk mengetahui gambaran kebiasaan merokok, $\mathrm{pH}$ saliva, keadaan OHIS, karies, gingivitis dan periodontitis. Analisa bivariat untuk mengetahui hubungan kebiasaan merokok dan $\mathrm{pH}$ saliva dengan 
Kesehatan Gigi dan Mulut (OHIS, karies, gingivitis dan periodontitis) pada Desa Patumbak I Kecamatan Patumbak Kabupaten Deli Serdang Analisa bivariat dengan Uji Statistik One Way Anova karena variabel bebas lebih dari dua kategori dan variabel terikat adalah variabel dengan skala ukur interval

Analisis Univariat

\section{HASIL PENELITIAN}

\section{Univariat}

Responden dalam penelitian ini berjumlah 128 orang diperoleh bahwa Responden yang Tidak Merokok adalah sebanyak 23 orang (18,0 \%), Perokok Ringan sebanyak 28 orang (21,3\%), Perokok Sedang sebanyak 50 orang (39,1\%) dan Perokok Berat sebanyak 27 orang (21,1\%), selanjutnya jumlah responden berdasarkan lama merokok $<5$ tahun sebanyak 35 orang (27,34\%), antara 5 - 10 tahun sebanyak 35 orang $(27,34 \%),>10$ tahun sebanyak 35 orang (27,34\%), sementara jumlah responden dengan keadaan $\mathrm{pH}$ saliva Asam sebanyak 23 orang (18\%), $\mathrm{pH}$ Saliva Netral sebanyak 65 orang (50,8 \%) dan ph Saliva Basa sebanyak 40 orang (31,2\%) sebagaimana dapat dilihat pada Tabel 5.1 di bawah ini.

\section{Analisis Bivariat}

1. Hubungan Merokok dengan Status Kesehatan Gigi dan Mulut

Status merokok adalah ada tidaknya serta banyaknya rokok yang dihisap seseorang setiap harinya sedangkan variabel Status kesehatan gigi dan mulut responden ditinjau dari hal yaitu Derajat Kebersihan Gigi (Debris Indeks dan Calkulus Indeks), Status Karies, Gingivitis dan Periodontitis

a. Hubungan Merokok dengan Indeks Debris

Rata-rata Indeks Debris pada kelompok masyarakat Tidak Merokok sebesar 1,12, pada kelompok Perokok Ringan sebesar 1,13, pada kelompok Perokok Sedang sebesar 1,49 dan pada kelompok Perokok Berat sebesar 1,40 , ada perbedaan yang signifikan $(p=0,011)$ yang berarti ada hubungan merokok dengan Indeks Debris masyarakat di Desa Patumbak I Kabupaten Deli Serdang Tahun 2017

Berdasarkan analisis antar kategori terdapat hubungan yang signifikan antara merokok dengan indeks debris antara perokok ringan dengan perokok sedang $(p=0,007)$, kemudian antara tidak merokok dengan perokok sedang $(\mathrm{p}=0,009)$

b. Hubungan Merokok dengan Indeks Kalkulus

Rata-rata Indeks Kalkulus pada kelompok masyarakat Tidak Merokok sebesar 1,56, pada kelompok Perokok Ringan sebesar 1,33, pada kelompok Perokok Sedang sebesar 1,73 dan pada kelompok Perokok Berat sebesar 1,12 , ada perbedaan yang signifikan $(p=0,001)$ yang berarti ada hubungan merokok dengan Indeks Kalkulus masyarakat di Desa Patumbak I Kabupaten Deli Serdang Tahun 2017

Berdasarkan analisis antar kategori terdapat hubungan yang signifikan antara merokok dengan indeks kalkulus antara perokok berat dengan perokok sedang
( $\mathrm{p}=0,000)$, antara perokok ringan dengan perokok sedang $(\mathrm{p}=0,009)$, kemudian antara tidak merokok dengan perokok berat $\{p=0,016)$

c. Hubungan Merokok dengan Indeks OHI-S (Kebersihan Mulut)

Rata-rata Indeks OHI-S pada kelompok masyarakat Tidak Merokok sebesar 2,67, pada kelompok Perokok Ringan sebesar 2,46, pada kelompok Perokok Sedang sebesar 3,20 dan pada kelompok Perokok Berat sebesar 2,51 , ada perbedaan yang signifikan $(p=0,006)$ yang berarti ada hubungan merokok dengan OHI-S masyarakat di Desa Patumbak I Kabupaten Deli Serdang Tahun 2017

Berdasarkan analisis antar kategori terdapat hubungan yang signifikan antara merokok dengan OHI-S antara perokok ringan dengan perokok sedang $(\mathrm{p}=0,003)$, antara perokok sedang dengan perokok berat $(\mathrm{p}=0,006)$, kemudian antara tidak merokok dengan perokok sedang $(p=0,043)$

d. Hubungan Merokok dengan Karies Gigi

Rata-rata Karies pada kelompok masyarakat Tidak Merokok sebesar 2,44, pada kelompok Perokok Ringan sebesar 2,89, pada kelompok Perokok Sedang sebesar 4,20 dan pada kelompok Perokok Berat sebesar 4,67, ada perbedaan yang signifikan $(p=0,000)$ yang berarti ada hubungan merokok dengan Angka Karies masyarakat di Desa Patumbak I Kabupaten Deli Serdang Tahun 2017

Berdasarkan analisis antar kategori terdapat hubungan yang signifikan antara merokok dengan Indeks Karies antara tidak merokok dengan perokok sedang $(\mathrm{p}=0,000)$, antara tidak merokok sedang dengan perokok berat $(\mathrm{p}=0,000)$, antara perokok ringan dengan perokok berat $(\mathrm{p}=0,001)$, kemudian antara perokok ringan dan perokok sedang $(\mathrm{p}=0,003)$

e. Hubungan Merokok dengan Gingivitis

Rata-rata Indeks Gingivitis pada kelompok masyarakat Tidak Merokok sebesar 0,044, pada kelompok Perokok Ringan sebesar 0,24, pada kelompok Perokok Sedang sebesar 0,03 dan pada kelompok Perokok Berat sebesar 0,025 , ada perbedaan yang signifikan $(p=0,021)$ yang berarti ada hubungan merokok dengan Angka Karies masyarakat di Desa Patumbak I Kabupaten Deli Serdang Tahun 2017

Berdasarkan analisis antar kategori terdapat hubungan yang signifikan antara merokok dengan Indeks Gingivitis antara tidak merokok dengan perokok sedang $(p=0,003)$

2. Hubungan Lama Merokok dengan Status Kesehatan Gigi dan Mulut

a. Hubungan Lama Merokok dengan Debris Indeks Rata-rata Indeks Debris pada kelompok masyarakat Tidak Merokok sebesar 1,12, pada kelompok Lama merokok $<5$ tahun sebesar 1,37, pada kelompok lama merokok 5 - 10 tahun sebesar 1,36 dan pada kelompok Perokok Berat sebesar 1,41, tidak ada perbedaan yang signifikan ( $p=0,268$ ) yang berarti tidak ada hubungan yang signifikan antara lama 
merokok dengan Indeks Debris masyarakat di Desa Patumbak I Kabupaten Deli Serdang Tahun 2017

b. Hubungan Lama Merokok dengan Indeks Kalkulus

Rata-rata Indeks Kalkulus pada kelompok masyarakat Tidak Merokok sebesar 1,56, pada kelompok lama merokok $<5$ tahun sebesar 1,44, pada kelompok lama merokok 5 - 10 tahun sebesar 1,54 dan pada kelompok lama merokok > 10 tahun sebesar 1,43, dengan demikian, tidak ada perbedaan yang signifikan ( $p=$ 0,826) yang berarti tidak ada hubungan merokok dengan Indeks Kalkulus masyarakat di Desa Patumbak I Kabupaten Deli Serdang Tahun 2017

c. Hubungan Lama Merokok dengan Indeks OHI-S (Kebersihan Mulut)

Rata-rata Indeks OHI-S pada kelompok masyarakat Tidak Merokok sebesar 2,67, pada kelompok lama merokok $<5$ tahun sebesar 2,81, pada kelompok lama merokok 5 - 10 tahun sebesar 2,87 dan pada kelompok lama merokok $<10$ tahun sebesar 2,80, tidak ada perbedaan yang signifikan ( $p=0,922$ ) yang berarti tidak ada hubungan lama merokok dengan OHI-S masyarakat di Desa Patumbak I Kabupaten Deli Serdang Tahun 2017

d. Hubungan Lama Merokok dengan Karies Gigi

Rata-rata Karies pada kelompok masyarakat Tidak Merokok sebesar 2,44, pada kelompok Perokok Ringan sebesar 2,89, pada kelompok Perokok Sedang sebesar 4,20 dan pada kelompok Perokok Berat sebesar 4,67, ada perbedaan yang signifikan $(p=0,000)$ yang berarti ada hubungan merokok dengan Angka Karies masyarakat di Desa Patumbak I Kabupaten Deli Serdang Tahun 2017

Berdasarkan analisis antar kategori terdapat hubungan yang signifikan antara lama merokok dengan Indeks Karies antara tidak merokok dengan lama merokok $>$ 10 tahun $(\mathrm{p}=0,000)$, antara lama merokok $<5$ tahun dengan lama merokok $>10$ tahun $(\mathrm{p}=0,001)$, antara lama merokok 5 - 10 tahun dengan lama merokok $>10$ tahun $(\mathrm{p}=0,004)$, antara tidak merokok dengan lama merokok $5-10$ tahun $(p=0,019)$,

e. Hubungan Lama Merokok dengan Gingivitis

Rata-rata Karies pada kelompok masyarakat Tidak Merokok sebesar 2,44, pada kelompok lama merokok $<5$ tahun sebesar 0,04, pada kelompok lama merokok 5 - 10 tahun sebesar 0,03 dan pada kelompok lama merokok $>10$ tahun sebesar 0,00

Berdasarkan analisis antar kategori terdapat hubungan yang signifikan antara lama merokok dengan Indeks Karies antara tidak merokok dengan lama merokok $>10$ tahun $(\mathrm{p}=0,002)$, antara tidak merokok dengan lama merokok 5 - 10 tahun $(\mathrm{p}=0,039)$, antara tidak merokok dengan lama merokok $5-10$ tahun $(\mathrm{p}=0,039)$

3. Hubungan $\mathrm{pH}$ Saliva dengan Status Kesehatan Gigi dan Mulut

pH Saliva adalah suatu keadaan yang menggambarkan keasaman air ludah yang akan dihubungkan dengan variabel Status kesehatan gigi dan mulut responden ditinjau dari hal yaitu Derajat Kebersihan Gigi (Debris
Indeks dan Calkulus Indeks), Status Karies, Gingivitis dan Periodontitis

a. Hubungan $\mathrm{pH}$ Saliva dengan Indeks Debris

Rata-rata Indeks Debris pada kelompok masyarakat dengan keadaan saliva Asam sebesar 1,81, pada kelompok Netral sebesar 1,16 dan pada kelompok Basa sebesar 1,33, ada perbedaan yang signifikan ( $p=$ 0,000 ) yang berarti ada hubungan $\mathrm{pH}$ Saliva dengan Indeks Debris masyarakat di Desa Patumbak I Kabupaten Deli Serdang Tahun 2017

Berdasarkan analisis antar kategori terdapat hubungan yang signifikan antara $\mathrm{pH}$ Saliva dengan Indeks Debris antara $\mathrm{pH}$ saliva Asam dengan Netral $(\mathrm{p}=0,000)$, dan antara $\mathrm{pH}$ saliva Asam dan Basa $(\mathrm{p}=0,001)$

b. Hubungan pH Saliva dengan Indeks Kalkulus

Rata-rata Indeks Kalkulus pada kelompok masyarakat dengan keadaan saliva Asam sebesar 1,48, pada kelompok Netral sebesar 1,31 dan pada kelompok Basa sebesar 1,77, ada perbedaan yang signifikan ( $p=$ $0,004)$ yang berarti ada hubungan $\mathrm{pH}$ Saliva dengan Indeks Kalkulus masyarakat di Desa Patumbak I Kabupaten Deli Serdang Tahun 2017

Berdasarkan analisis antar kategori terdapat hubungan yang signifikan antara $\mathrm{pH}$ Saliva dengan Indeks Kalkulus antara $\mathrm{pH}$ saliva Netral dengan Basa $(p=0,001)$

c. Hubungan $\mathrm{pH}$ Saliva dengan OHI-S

Rata-rata OHI-S pada kelompok masyarakat dengan keadaan saliva Asam sebesar 3,25, pada kelompok Netral sebesar 2,46 dan pada kelompok Basa sebesar 3,09 , ada perbedaan yang signifikan $(p=0,001)$ yang berarti ada hubungan $\mathrm{pH}$ Saliva dengan Indeks Kalkulus masyarakat di Desa Patumbak I Kabupaten Deli Serdang Tahun 2017

Berdasarkan analisis antar kategori terdapat hubungan yang signifikan antara $\mathrm{pH}$ Saliva dengan OHI-S antara $\mathrm{pH}$ saliva Asam dengan Netral $(\mathrm{p}=0,002)$, dan antara $\mathrm{pH}$ saliva Netral dan Basa $(\mathrm{p}=0,003)$

d. Hubungan pH Saliva dengan Karies

Rata-rata Karies pada kelompok masyarakat dengan keadaan saliva Asam sebesar 4,44, pada kelompok Netral sebesar 3,74 dan pada kelompok Basa sebesar 3,13 , ada perbedaan yang signifikan $(p=0,039)$ yang berarti ada hubungan $\mathrm{pH}$ Saliva dengan Karies gigi masyarakat di Desa Patumbak I Kabupaten Deli Serdang Tahun 2017

Berdasarkan analisis antar kategori terdapat hubungan yang signifikan antara $\mathrm{pH}$ Saliva dengan Karies antara $\mathrm{pH}$ saliva Asam dengan Basa $(\mathrm{p}=0,012)$

e. Hubungan $\mathrm{pH}$ Saliva dengan Gingivitis

Rata-rata Gingivitis pada kelompok masyarakat dengan keadaan saliva Asam sebesar 0,052, pada kelompok Netral sebesar 0,011 dan pada kelompok Basa sebesar 0,17 , ada perbedaan yang signifikan $(p=0,007)$ yang berarti ada hubungan $\mathrm{pH}$ Saliva dengan Gingivitis masyarakat di Desa Patumbak I Kabupaten Deli Serdang Tahun 2017

Berdasarkan analisis antar kategori terdapat hubungan yang signifikan antara $\mathrm{pH}$ Saliva dengan Gingivitis 
antara $\mathrm{pH}$ saliva Asam dengan Netral $(\mathrm{p}=0,002)$, dan antara $\mathrm{pH}$ saliva Asam dan Basa $(\mathrm{p}=0,014)$

\section{PEMBAHASAN}

Jumlah responden penelitian sebanyak 128 responden, dari hasil wawancara dan pemeriksaan diperoleh bahwa jumlah responden yang Tidak Merokok adalah sebesar 18,0\%, Perokok Ringan sebesar 21,3 \%, Perokok Sedang sebesar 39,1\% dan Perokok Berat sebesar $21,1 \%$

Menurut Tobacco Atlas $3^{\text {rd }}$ Edition, 2019 bahwa persentase penduduk dunia yang mengkonsumsi tembakau didapatkan sebanyak 57\% pada penduduk Asia dan Australia, sementara di Asean Indonesia merupakan Negara yang mengkonsumsi rokok terbesar 46,16 \%. Berdasarkan Riskedas 2013 bahwa jumlah perokok di Indonesia masih tinggi yaitu perokok setiap hari $24,3 \%$, perokok kadang-kadang 5,5 \% dan mantan perokok 4\%. Senada dengan hal di atas bahwa di wilayah kecamatan Patumbak kita jumpai persentase perokok yang masih besar

Selanjutnya jumlah responden dengan keadaan $\mathrm{pH}$ saliva Asam sebanyak 23 orang (18\%), pH Saliva Netral sebanyak 65 orang (50,8 \%) dan ph Saliva Basa sebanyak 40 orang $(31,2 \%)$. Keadaan Netral pH saliva sekitar 7. Dalam keadaan fisiologis pH saliva berkisar antara 6,5-7,4 (Pederson et al., 2002). Membuktikan pH ormal merupakan persentase yang lebih banyak. Hal ini dipengaruhi oleh laju aliran saliva dan kapasitas buffer dari saliva. Konsentrasi bikarbonat mempengaruhi kapasitas buffer dalam saliva. Laju aliran saliva meningkat, kapasitas buffer juga meningkat. Peningkatan dua faktor tersebut berpengaruh dalam proses pembersihan bakteri ataupun antigen yang ada dalam rongga mulut.

Menurut Ramadhan 2010, merokok menjadi penyebab terbesar timbulnya masalah kesehatan ataupun kebersihan gigi dan mulut yang dapat dilihat dari Debris, kalkulus, OHI-S, dan Gingivitis

Hasil uji statistik tentang hubungan merokok dengan Indeks Debris dengan nilai p = 0,011 menunjukkan bahwa terdapat hubungan yang signifikan antara status merokok dengan debris, selanjutnya hubungan merokok dengan indeks kalkulus dengan nilai $\mathrm{p}=0,001$ menunjukkan bahwa terdapat hubungan yang signifikan antara status merokok dengan kalkulus dan hubungan merokok dengan OHI-S dengan nilai $\mathrm{p}=0,006$ hal ini menunjukkan bahwa terdapat hubungan yang signifikan antara status merokok dengan Kebersihan Gigi dan Mulut responden

Hal ini sesuai dengan penelitian FX, Sintawati dkk, 2017 pada masyarakat DKI Jakarta, ada hubungan signifikan antara kebiasaan merokok dengan keberihan gigi dan mulut dengan $\mathrm{p}=0,002$ dimana kebersihan gigi dan mulut (OHI-S) adalah jumlah dari Indeks Debris dan Indeks Kalkulus.

Dari beberapa kebiasaan buruk lainnya, merokok menjadi penyebab terbesar timbulnya masalah kesehatan ataupun kebersihan gigi dan mulut (Rahmadhan, 2010)
Wardianto 2010 menyebutkan bahwa pengaruh merokok pada mukosa mulut bervariasi, tergantung pada umur, jenis kelamin, etnis, gaya hidup, diet, genetis, jenis, dan cara merokok, serta lamanya merokok. Perubahan tersebut akibat iritan, toksin dan karsinogen. Salah satu bagian tubuh yang paling riskan terpapar efek merugikan dari rokok adalah rongga mulut yang merupakan tempat awal terjadinya penyerapan zat-zat hasil pembakaran rokok. Merokok dapat menyebabkan kelainan-kelainan rongga mulut misalnya pada gusi, mukosa mulut, gigi, langit-langit yang berupa stomatitis nikotina dan infeksi jamur serta pada lidah yang berupa terjadinya perubahan sensitivitas indera pengecap. Asap panas yang berhembus terus menerus ke dalam rongga mulut merangsang perubahan aliran darah dan mengurangi sekresi saliva. Temperatur rokok pada bibir adalah $30^{\circ} \mathrm{C}$, sedangkan ujung rokok yang terbakar dapat mencapai suhu $900^{\circ} \mathrm{C}$. Hal ini menyebabkan rongga mulut menjadi kering dan lebih anaerob sehingga memberikan lingkungan yang sesuai untuk timbulnya bakteri anaerob dalam plak

Gigi geligi seorang perokok cenderung lebih banyak terdapat karang gigi daripada yang bukan perokok. Karang gigi yang tidak dibersihkan dapat menimbulkan berbagai keluhan, seperti gingivitis atau gusi berdarah. Selain itu, hasil pembakaran rokok dapat menyebabkan gangguan sirkulasi darah ke gusi sehingga mudah terjadi penyakit (Wardianto 2010)

Berdasarkan analisis antar kategori terdapat hubungan yang signifikan antara merokok dengan indeks debris antara perokok ringan dengan perokok sedang $(p=0,007)$, antara tidak merokok dengan perokok sedang $(\mathrm{p}=0,009)$, terdapat hubungan yang signifikan antara merokok dengan indeks kalkulus antara perokok berat dengan perokok sedang $(p=0,000)$, antara perokok ringan dengan perokok sedang $(\mathrm{p}=0,009)$, dan antara tidak merokok dengan perokok berat $(\mathrm{p}=0,016)$, terdapat hubungan yang signifikan antara merokok dengan OHI-S antara perokok ringan dengan perokok sedang $(\mathrm{p}=0,003)$, antara perokok sedang dengan perokok berat $(\mathrm{p}=0,006)$, dan antara tidak merokok dengan perokok sedang $\{\mathrm{p}=0,043)$

Sesuai dengan penelitian Andina Rizkia Putri Kusuma, 2012 Hasil pembakaran rokok mengandung berbagai jenis toksin dan agen karsinogen yang dapat membahayakan, tidak hanya pada orang yang merokok (perokok aktif), tetapi juga pada orang disekitar perokok (perokok pasif). Selain dapat menyebabkan terjadinya penyakit sistemik seperti kanker paru, penyakit kardiovaskuler, risiko terjadinya neoplasma larynx, esophagus, merokok juga terbukti berhubungan dengan munculnya berbagai kelainan gigi dan rongga mulut

Hasil Uji Statistik tentang merokok dengan keadaan karies gigi masyarakat menunjukkan bahwa ada perbedaan yang signifikan $\mathrm{p}=0,000$ yang berarti ada hubungan merokok dengan keadaan karies gigi masyarakat di Desa Patumbak I Kabupaten Deli Serdang Tahun 2017.

Sesuai dengan penelitian drg Wasis dilakukan menggunakan data dari 34.534 responden Riskesdas tahun 2007. Penelitian dilakukan dengan membandingkan data umur, pekerjaan, status sosial serta frekuensi menggosok gigi dengan kebiasaan merokok para responden. Hasil 
penelitian menunjukkan ada kaitan signifikan antara kebiasaan merokok dengan risiko terserang karies gigi. Pada perokok berat, 38,7 persennya mengidap karies gigi parah. Sementara pada perokok ringan, 32,5 persen yang mengidap karies gigi parah. Di sisi lain, nonperokok juga berpotensi memiliki karies gigi, meskipun lebih kecil persentasenya, hanya 24,9 persen. drg Wasis mengatakan pada nonperokok, karies timbul karena berbagai macam faktor. Sementara itu penelitian lain oleh Widijanto Sudhana, 2000 ada hubungan merokok dengan insidensi karies berdasarkan data-data epidemiologi.

Perokok lebih rentan menderita karies gigi spesifik jika sudah merokok lebih dari 10 tahun dan 18 batang perharinya. Lama merokok dan jumlah rokok yang dihisap adalah faktor yang mempengaruhi derajat kerusakan gigi. Salah satu gangguan periodontium akibat merokok adalah caries dentis. Pada manusia modern yang hidup dalam masyarakat industri yang sudah maju, caries merupakan hal yang sudah biasa, tetapi frekuensi caries berbeda di tiap negeri dan di antara individu itu sendiri (Kidd.and Joyston, 1992)

Hasil Uji Statistik tentang merokok dengan gingivitis pada masyarakat menunjukkan bahwa ada perbedaan yang signifikan $p=0,021$ yang berarti ada hubungan merokok dengan gingivitis pada masyarakat di Desa Patumbak I Kabupaten Deli Serdang Tahun 2017

Merokok akan merusak mikrosirkulas dalam gingiva sehingga secara kronis bagian dari jaringan gingiva yang divaskularisasi oleh kapiler-kapiler akan kekurangan oxygen dan bahan-bahan nutrisi yang diperlukan (Nurul, 2010). Berbagai macam rokok dan intensitas kebiassaan merokok telah terbukti mempunyai hubungan kuat dengan status jaringan gingiva,

Berdasarkan penelitian oleh Fouad $\mathrm{H}$ Al-Bayaty dan kawan-kawan di Malaysia menunjukkan bahwa durasi merokok dalam beberapa tahun berhubungan dengan keadaan pendarahan pada gingival dan pembentukan plak pada perokok, penelitian lain yang dilakukan oleh Katarina D. Manibuy dan kawan-kawan di Menado menunjukkan 70,7 \% remaja usia 15 - 19 tahun yang memiliki kebiasaan merokok memiliki status gingivitis ringan.

Dari hasil penelitian Ninik L.Pratiwi 2000, dapat disimpulkan bahwa terjadi peningkatan risiko gingivitis pada perokok seiring dengan meningkatnya jumlah batang rokok yang dihisap per hari. Resiko kejadian gingivitis 10 kali lebih banya dlbandingkan lldak merokok. Demikian pula pada kelompok usia, dengan semakin lanjut usia tingkat keparahan gingivitis juga bertambah. Ada risiko peningkatan tejedinya gingivitis dengan semakin bertambahnya usia. Analisa trend kejadian gingivitis juga meningkat dengan semakin jeleknya Oral hygiene lndek pada perokok. Namun ada tidaknya karies gigi pada perokok tidak terjadi peningkatan gingivitis

Nilai $p=0,268$ yang berarti tidak ada hubungan yang signifikan antara lama merokok dengan Indeks Debris, $p=0,826$ yang berarti tidak ada hubungan merokok dengan Indeks Kalkulus dann $p=0,922$ menunjukkan tidak ada hubungan lama merokok dengan OHI-S masyarakat di Desa Patumbak I Kabupaten Deli Serdang Tahun 2017
Hal ini bertentangan dengan Penelitian Putri Amalia, 2009 bahwa pada tukang becak di Kelurahan Tanjung Rejo Kota Medan, Kebiasaan merokok, jumlah rokok dan lama merokok berhubungan secara signifikan terhadap skor OHIS dan skor IPPD namun memberikan pengaruh yang tidak signifikan dengan skor IP.

Nilai ( $p=0,000)$ yang berarti ada hubungan merokok dengan Angka Karies masyarakat di Desa Patumbak I Kabupaten Deli Serdang Tahun 2017. Sejalan dengan penelitian Anggun Dessita Wandastuti, 2010 pada pengunjung Puskesmas Srondol kota Semarang bahwa: Lama merokok sebagai faktor risiko buruknya aliran sekresi saliva $(\mathrm{p}=0,005$ dan $\mathrm{OR}=18,2)$

Nilai $(p=0,013)$ yang berarti ada hubungan merokok dengan Gingivitis masyarakat di Desa Patumbak I Kabupaten Deli Serdang Tahun 2017 sejalan dengan penelitian 1 Katarina D. Manibuy, penelitian pada remaja usia 15-19 tahun. Hasil uji chi-sqaure menunjukkan bahwa tidak terdapat hubungan antara kebiasaan merokok berdasarkan jumlah rokok dengan status gingiva $(p>0,05)$ namun kebiasaan merokok berdasarkan lama merokok berhubungan dengan status gingiva $((\mathrm{p}<0,05)$

Hasil uji statistik terhadap perbedaaan keasaman $\mathrm{pH}$ saliva terhadap debris dengan nilai $p=0,000$ yang berarti ada hubungan $\mathrm{pH}$ Saliva dengan Indeks Debris, selanjutnya uji statistic terhadapap perbedaah $\mathrm{pH}$ saliva dengan kalkulus dengan nilai $p=0,004$ yang berarti ada hubungan $\mathrm{pH}$ Saliva dengan kalkulus gigi dan hasil uji statistik terhadap perbedaan $\mathrm{pH}$ saliva terhadap Indeks kebersihan gigi dan mulut (OHI-S) dengan nilai $p=0,001$ yang berarti ada hubungan $\mathrm{pH}$ Saliva dengan Indeks kebersihan gigi dan mulut (OHI-S) pada masyarakat di Desa Patumbak I Kabupaten Deli Serdang Tahun 2017

Kenaikan $\mathrm{pH}$ saliva yang membuat suasana rongga mulut menjadi basa dapat membentuk kristal-kristal yang menyimpang sehingga terjadi pembentukan karang gigi atau kalkulus (Amerongen 1988). Kalkulus adalah jenis kalsifikasi patologis yang berhubungan dengan penyakit periodontal, merupakan jenis plak yang terkalsifikasi dan deposit terkalsifikasinya dibedakan menurut hubungannya dengan tepi gingiva, yaitu kalkulus supragingiva dan subgingiva. Mineral dari kalkulus supragingiva berasal dari saliva sedangkan pada kalkulus supragingiva berasal dari eksudat cairan gingiva (Manson \& Elley 1993)

Peran lain dari saliva adalah fungsinya dalam pembentukan pelikel yang kemudian akan berkembang menjadi plak gigi. Plak gigi adalah suatu lapisan lunak yang terdiri dari kumpulan mikroorganisme yang berkembang biak di atas suatu matriks yang terbentuk dan melekat erat pada permukaan gigi yang tidak dibersihkan (Pintauli \& Hamada 2010). Lapisan lunak plak terbentuk dari deposit selapis tipis protein saliva yang terutama terdiri dari glikoprotein pada permukaan gigi. Lapisan ini yang disebut pelikel dan hanya dapat dilepas dengan pembersihan mekanis ini mengakibatkan perubahan tingkat kebersihan gigi dan mulut

Hasil uji statistik terhadap perbedaaan keasaman $\mathrm{pH}$ saliva terhadap karies gigi dengan nilai $(p=0,039)$ yang berarti ada hubungan $\mathrm{pH}$ Saliva dengan Karies gigi 
pada masyarakat di Desa Patumbak I Kabupaten Deli Serdang Tahun 2017

Sesuai dengan penelitian yang dilakukan oleh Kartika Sulia Sulendra, dkk 2013 pada sekelompok siswa dengan kesimpulan penelitian ini adalah tidak ada hubungan yang signifikan antara $\mathrm{pH}$ dan viskositas saliva dengan indeks DMF-T pada siswa-siswi SD Baletbaru I dan Baletbaru II. Jember

Tarigan (1993), menuliskan bahwa $\mathrm{pH}$ normal saliva berkisar antara 6,2 - 7,4. pH saliva yang rendah dan mencapai angka kritis dapat menyebabkan terjadinya karies atau lubang pada gigi, di mana penurunan $\mathrm{pH}$ yang berulangulang dalam waktu tertentu akan mengakibatkan demineralisasi permukaan gigi. Karies gigi ini merupakan salah satu efek samping dari rokok, di mana seperti yang telah dituliskan di atas bahwa rokok secara signifikan menurunkan $\mathrm{pH}$ saliva sehingga menjadi lebih asam dan lebih berpotensi terjadi karies gigi

Hasil uji statistik terhadap perbedaaan keasaman $\mathrm{pH}$ saliva terhadap gingivitis dengan nilai $(p=0,021)$ yang berarti ada hubungan $\mathrm{pH}$ Saliva dengan gingivitis pada masyarakat di Desa Patumbak I Kabupaten Deli Serdang Tahun 2017

Sesuai dengan Teori Manson \& Elley bahwa dalam waktu beberapa menit setelah terdepositnya pelikel, pelikel akan terpopulasi dengan bakteri. Pembentukan plak supragingiva dipelopori oleh bakteri yang memiliki kemampuan untuk membentuk polisakarida ekstraselular. Koloni bakteri yang pertama adalah Streptococcus Mitior, S. Sanguis, Actinomyces Viscocus dan A. Naeslundii. Bila bakteri ini dibiarkan tumbuh beberapa hari, akan menyebabkan inflamasi gingiva (Manson \& Elley 1993)

\section{KESIMPULAN DAN SARAN}

\section{Kesimpulan}

a. Sebanyak128 responden, jumlah terbanyak adalah Perokok Sedang 39,1\%, Perokok Ringan 21,3 \%, dan Perokok Berat 21,1\%, Tidak Merokok18,0\%, sedangkan menurut $\mathrm{pH}$ saliva jumlah terbesar pada pH Saliva Netral 50,8 \%, Basa 31,2\% dan Asam $18 \%$

b. Ada hubungan yang signifikan antara merokok dengan status kebersihan gigi dan mulut (Debris $\mathrm{p}=0,011$; Kalkulus $\mathrm{p}=0,001$; OHI-S $\mathrm{p}=0,006$ ), Karies $(p=0,000)$ dan Gingivitis $(p=0,021)$ pada masyarakat di Desa Patumbak I Kecamatan Patumbak Kabupaten Deli Serdang

c. Ada hubungan yang signifikan dengan Lama Merokok dengan Karies $\mathrm{p}=0,000$ dan Gingivitis $\mathrm{p}=0,013$ sedangkan lama merokok dengan status kebersihan gigi dan mulut tidak ada hubungan yang signifikan (Debris $\mathrm{p}=0,268$; Kalkulus $\mathrm{p}=0,826$; OHI-S $\mathrm{p}=0,922$ )

d. Ada hubungan yang signifikan antara pH Saliva dengan status kebersihan gigi dan mulut (Debris $\mathrm{p}=0,000$; Kalkulus $\mathrm{p}=0,004$; OHI-S $\mathrm{p}=0,001$ ), Karies $(p=0,039)$ dan Gingivitis $(p=0,007)$ pada masyarakat di Desa Patumbak I Kecamatan Patumbak Kabupaten Deli Serdang

\section{Saran}

a. Kepada masyarakat dianjurkan untuk menghindari rokok untuk menjaga kesehatan gigi dan mulut pribadi keluarga dan masyarakat

b. Diadakannya dilakukan penyuluhan tentang bahaya merokok terhadap kesehatan umumnya dan penyakit gigi dan mulut khususnya kepada masyarakat di Desa Patumbak I Kecamatan Patumbak Kabupaten Deli Serdang

c. Diadakannya dilakukan penyuluhan tentang manipulasi $\mathrm{pH}$ saliva mulutuntuk mencegah terjadinya penyakit gigi dan mulut khususnya

d. Menyarankan kepada Aparat Pemerintah setempat untuk melakukan kampanye anti merokok pada masyarakat

e. Menyebarluaskan informasi tentang kesehatan gigi dan mulut pada masyarakat Kecamatan Patumbak Kabupaten Deli Serdang melalui media yang ada yang dapat terjangkau

f. Hendaknya dilakukan penelitian berkelanjutan tentang kesehatan gigi dan mulut pada masyarakat Kecamatan Patumbak Kabupaten Deli Serdang sehingga masalah-masalah kesehatan gigi dan mulut dapat terjawab

\section{DAFTAR PUSTAKA}

Aditama, T. 2013. Tuberkulosis, Rokok. Dan Perempuan. Jakarta: Fakultas Kedokteran Universitas Indonesia

Aditama, T. 2014. Rokok dan Kesehatan. Jakarta:Fakultas Kedokteran Universitas Indonesia

Anggun DW, 2010Lama merokok sebagai faktor risiko buruknya aliran sekresi saliva pada pengunjung Puskesmas Srondol kota Semarang

Aniyuna, 2013. Pengaruh Merokok pada pH saliva, http://aniyuna93.blogspot. co.id/013/11/makalah-pengaruh-merokok-padapHsaliva.html (diakses 29 Februari2017)

Irma, I. 2013. Penyakit Gigi, Mulut dan THT. Yogyakarta: Nuha Medika

Jaya, M. 2012. Pembunuh Berbaya Itu Bernama Rokok. Yogyakarta: Riz'ma

Kemeterian Kesehatan Republik Indonesia, "Infodatin Pusat data dan Informasi Kementerian Kesehatan RI”, Jakarta 2013

Komalasari, 2005. Faktor-faktor penyebab perilaku merokok Jurnal Psikologi Universitas Gadjah Mada, Yogyakarta. http://www.google.com/jurnal. psikologi. ugm.ac.index.article (diakses 5 April 2017)

Kidd, Edwina A. M \& Bechal, S J.2013. Dasar-Dasar Karies. Jakarta: sEGC

Martariwansyah. 2008. Gigiku Kuat, Mulutku Sehat.Bandung: Hayati Qualita

Mubeen. K, Chandrashekhar. H, Kavitha M, Nagarathna S. 2013 Journal Effect Of Tobacco On Oral-Health An Overview 
Notoadmodjo, S. 2005. Metodi Penelitian Kesehatan. Jakarta : Rineka Cipta

Notoadmodjo, S. 2010. Metodi Penelitian Kesehatan. Jakarta : Rineka Cipta

Pintauli, S \& Hamada, T. 2012. Menuju Gigi \& Mulut sehat Pencegahan dan Pemeliharaan. Medan: USU Press

Riskesdas. 2013. Laporan Nasional Riskesda 2013

Hhtp://litbag.depkes.go.id (diakses tanggal : 29 November 2016)
Sumartono, W. 2015. Rokok Bisa Sebabkan Gigi Berlubang,http://www.beritasatu.com/kesehatan /293697-ini-penjelasan-rokok-bisa-sebabkangigi-berlubang.html. (diakses 29 Februari2017)

Tarigan, Rasinta. Karies Gigi. 2012. Jakarta: EGC Wiarto, Giri. Budaya Hidup Sehat. 2013. Jakarta: Gosyen Publishing 